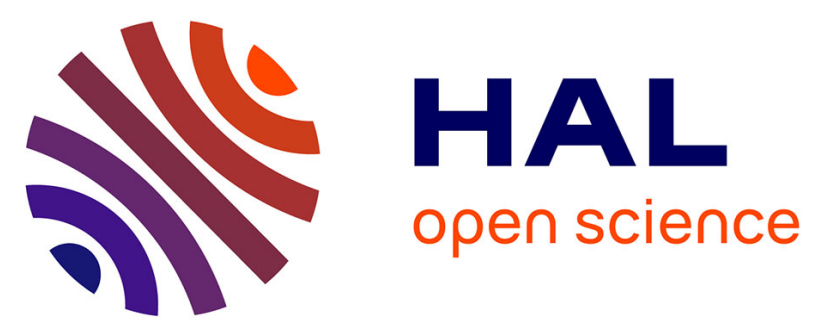

\title{
Deacetylation of chiral ferrocenyl-containing $\beta$-diketones promoted by ethylene diamine: Spectroscopic and structural characterization of the fragmentation products
}

Guillermo Ahumada, Juan Pablo Soto, David Carrillo, Carolina Manzur, Thierry Roisnel, Jean-René Hamon

\section{To cite this version:}

Guillermo Ahumada, Juan Pablo Soto, David Carrillo, Carolina Manzur, Thierry Roisnel, et al.. Deacetylation of chiral ferrocenyl-containing $\beta$-diketones promoted by ethylene diamine: Spectroscopic and structural characterization of the fragmentation products. Journal of Organometallic Chemistry, 2014, 770, pp.14 - 20. 10.1016/j.jorganchem.2014.07.019 . hal-01074972

HAL Id: hal-01074972

https://hal-univ-rennes1.archives-ouvertes.fr/hal-01074972

Submitted on 16 Oct 2014

HAL is a multi-disciplinary open access archive for the deposit and dissemination of scientific research documents, whether they are published or not. The documents may come from teaching and research institutions in France or abroad, or from public or private research centers.
L'archive ouverte pluridisciplinaire HAL, est destinée au dépôt et à la diffusion de documents scientifiques de niveau recherche, publiés ou non, émanant des établissements d'enseignement et de recherche français ou étrangers, des laboratoires publics ou privés. 
Ms. Ref. No.: JORGANCHEM-D-14-00359

Revised Manuscript

\section{Deacetylation of chiral ferrocenyl-containing $\beta$-diketones promoted by ethylene diamine: Spectroscopic and structural characterization of the fragmentation products}

\section{Guillermo Ahumada ${ }^{\mathrm{a}}$, Juan Pablo Soto ${ }^{\mathrm{b}}$, David Carrillo ${ }^{\mathrm{a}}$, Carolina Manzur ${ }^{\mathrm{a}}$, Thierry Roisnel ${ }^{\mathrm{c}}$, Jean-René Hamon ${ }^{\mathrm{d}}$ *}

aaboratorio de Química Inorgánica, Instituto de Química, Pontificia Universidad Católica de Valparaíso, Campus Curauma, Avenida Universidad 330, Valparaíso, Chile baboratorio de Química Orgánica 1, Instituto de Química, Pontificia Universidad Católica de Valparaíso, Campus Curauma, Avenida Universidad 330, Valparaíso, Chile cUMR 6226 «Institut des Sciences Chimiques de Rennes», CNRS-Université de Rennes 1, Centre de Diffractométrie X, Campus de Beaulieu, 35042 Rennes Cedex, France

${ }^{d}$ UMR 6226 «Institut des Sciences Chimiques de Rennes», CNRS-Université de Rennes 1, Campus de Beaulieu, 35042 Rennes Cedex, France

Corresponding authors. Phone: +56 3222749 32, E-mail address: cmanzur@ucv.cl (C. Manzur); Phone: +33 2232359 58, E-mail address: jean-rene.hamon@univ-rennes1.fr (J.-R. Hamon). 


\begin{abstract}
It is well known that $\beta$-diketones react with primary amines, readily forming the corresponding Schiff base derivatives. However, in the present case, the chiral ferrocenyl-containing $\beta$-diketones, 3-(1-ferrocenylethyl)-pentane-2,4-dione (1a), 1-(4methoxyphenyl)-2-(1-ferrocenylethyl)-butane-1,3-dione (1b), and 1-ferrocenyl-2-(1ferrocenylethyl)-butane-1,3-dione (1c) react with ethylene diamine under acidic conditions in refluxing toluene to yield, unexpectedly, their deacetylated counterparts, 3-ferrocenyl-butane-2-one (2a), 1-(4-methoxyphenyl)-3-ferrocenyl-butane-1-one (2b), and 1,3-bisferrocenyl-butane-2-one (2c), respectively. Such deacetylation reactions are accompagned by the formation of 2-methyl-2-imidazoline. A reaction mechanism involving an intramolecular Michael addition followed by a retro-Mannich rearrangement is suggested. The ketones $\mathbf{2 a - c}$ are fully characterized by analytical and spectroscopic methods. Additionally, compounds 2a and $\mathbf{2 c}$ are authenticated by single crystal X-ray diffraction analysis. The electrochemical behaviour of the bimetallic complex $\mathbf{2 c}$ is also investigated.
\end{abstract}

Keywords: Ferrocenyl; Chiral $\beta$-Diketones; Ethylene Diamine; Deacetylation; Michael Addition; Retro-Mannich Rearrangement 


\section{Introduction}

Rational design and synthesis of acyclic or cyclic Schiff base metal complexes are of permanent interest [1-4], mainly due to their applications in numerous fields of chemistry varying from catalysis [5-12] to the synthesis of pharmaceuticals [13-18], including new functional molecular-based materials [17-22] with second-order nonlinear optical (NLO) properties [23-29]. In the latter case, the non-centrosymmetric crystal structure is a critical consideration for the design of materials with large secondorder nonlinearities although the chiral enantiopure compounds tend to crystallize in a non-centrosymmetrical space group [30]. In general, Schiff base ligands are easily available owing to low cost starting materials and facile synthesis. Furthermore, they show stability, high tunability and flexibility that could enable the tuning of the electronic properties and steric demands of their metal complexes [31,32]. The unsymmetrical acyclic Schiff bases are obtained by stepwise condensation of formyl- or keto- group and primary diamine precursors, whereas the mono-condensation of an appended $\mathrm{O}, \mathrm{N}$ or $\mathrm{S}$ donor groups containing primary amine with aldehydes or ketones leads to the formation of tridentate Schiff bases, also called "half units" [33,34], through the imine, $\mathrm{O}, \mathrm{N}$ or $\mathrm{S}$ donor groups and the carbonyl oxygen [35-37]. Their deprotonated forms, the anionic $\mathrm{O}, \mathrm{N}, \mathrm{X}$-donor Schiff bases $(\mathrm{X}=\mathrm{O}, \mathrm{N}, \mathrm{S})$ can be considered as "pincer-like" ligands [33]. They could, therefore, serve as good chelating ligands for transition metals with, for instance, potential applications in catalysis [38,39].

Along this line, in pursuit of our research work aimed at designing new pushpull unsymmetrical Schiff base complexes exhibiting NLO properties [26], we were interested in the preparation of novel $\mathrm{O}, \mathrm{N}, \mathrm{N}$ tridentate metalloligands by reacting the three chiral ferrocenyl-containing $\beta$-diketones that we reported previously [40], namely, 3-(1-ferrocenylethyl)-pentane-2,4-dione (1a), 1-(4-methoxyphenyl)-2-(1ferrocenylethyl)-butane-1,3-dione (1b), and 1-ferrocenyl-2-(1-ferrocenylethyl)-butane1,3-dione (1c), with 1,2-ethylenediamine through a Schiff base monocondensation reaction. Unexpectedly, we isolated the fragmentation products $\mathrm{Fc}-\mathrm{CH}\left(\mathrm{CH}_{3}\right) \mathrm{CH}_{2} \mathrm{C}(=\mathrm{O}) \mathrm{R}(\mathrm{R}$ $\left.=\mathrm{Me}, \mathbf{2} \mathbf{a} ; 4-\mathrm{MeO}-\mathrm{C}_{6} \mathrm{H}_{4}, \mathbf{2 b} ; \mathrm{Fc}, \mathbf{2} \mathbf{c} ; \mathrm{Fc}=\left(\eta^{5}-\mathrm{C}_{5} \mathrm{H}_{5}\right) \mathrm{Fe}\left(\eta^{5}-\mathrm{C}_{5} \mathrm{H}_{4}\right)\right)$. Herein, we wish to describe the synthesis, the full analytical and spectroscopic characterization, and the electrochemical behaviour of the three chiral ferrocenyl-containing ketones $\mathbf{2 a - c}$, as well as some mechanistic aspects of their formation. In addition, the crystal and molecu- 
lar structures of the monometallic complex 4-ferrocenyl-pentane-2-one (2a) and of the binuclear derivative 1,3-bisferrocenyl-butane-1-one (2c) were determined by X-ray single crystal diffraction analysis. The electrochemical behaviour of this latter complex 2c was also investigated by cyclic voltammetry.

\section{Experimental}

\subsection{General experimental methods}

Reactions were performed under dry dinitrogen atmosphere using standard Schlenk techniques. Solvents were dried and distilled under dinitrogen by standard methods prior to use. All chemicals were purchased from commercial sources and used without further purification. Compounds 3-(1-ferrocenylethyl)-pentane-2,4-dione (1a), 1-(4-methoxyphenyl)-2-(1-ferrocenylethyl)-butane-1,3-dione (1b), and 1-ferrocenyl-2(1-ferrocenylethyl)-butane-1,3-dione (1c) where synthesized following our previously reported procedure [40]. Infrared spectra were recorded from $\mathrm{KBr}$ disks on a Perkin Elmer model 1600 FT-IR spectrophotometer, in the range $4000-450 \mathrm{~cm}^{-1} .{ }^{1} \mathrm{H}$ and ${ }^{13} \mathrm{C}$ NMR spectra were recorded on a Bruker Avance III 400 spectrometer in $\mathrm{CDCl}_{3}$ solutions at $298 \mathrm{~K}$. Chemical shifts $(\delta)$ are reported in parts per million (ppm) and referenced to the residual deuterated solvent peaks $\left(\mathrm{CDCl}_{3}:{ }^{1} \mathrm{H} \delta=7.26 \mathrm{ppm},{ }^{13} \mathrm{C} \delta=\right.$ $77.16 \mathrm{ppm})$. Coupling constants $(J)$ are expressed in hertz $(\mathrm{Hz})$. Microanalyses were conducted on a Thermo-FINNIGAN Flash EA 1112 CHNS/O analyzer by the Microanalytical Service of the Centre Régional de Mesures Physiques de l'Ouest (CRMPO) at the University of Rennes 1, France. Migration coefficients $\left(\mathrm{R}_{\mathrm{f}}\right)$ were determined on silica gel TLC plates. Melting points were measured in evacuated capillaries on a Kofler Bristoline melting point apparatus and are uncorrected. Cyclic voltammetry $(\mathrm{CV})$ measurements were performed with a Radiometer Analytical model PGZ 100 all in one potentiostat, using a three-electrode cell equipped with glassy carbon working, $\mathrm{Ag} / \mathrm{AgCl}$ reference and platinum wire auxiliary electrodes. The ferrocene/ferricenium redox couple $\left(\mathrm{FcH}^{0 /+}\right)$ was located at $\mathrm{E}_{1 / 2}=0.510 \mathrm{~V}$, where $\mathrm{E}_{1 / 2}$ was calculated from the average of the oxidation and reduction peak potentials. 


\subsection{Synthesis}

\subsubsection{General procedure}

At room temperature (rt), a three necked round-bottomed flask was charged with the appropriate amount of the chiral diketone, toluene and $5 \mu \mathrm{L}(0.08 \mathrm{mmol})$ of glacial acetic acid. The solution was stirred for $5 \mathrm{~min}$ before the addition by syringe of 1,2ethylene diamine. The reaction mixture was refluxed for $12 \mathrm{~h}$, and upon cooling to rt the resulting solution was evaporated under reduced pressure to eliminate the excess of ethylene diamine and glacial acetic acid. The crude mixture was chromatographed $(3 \mathrm{x}$ $24 \mathrm{~cm}$ ) using silica gel (70-230 mesh) with a mixture of hexane/ethyl acetate as eluent. The collected solutions were dried over $\mathrm{MgSO}_{4}$, filtered and the solvent evaporated under vacuum.

\subsubsection{4-Ferrocenyl-pentane-2-one (2a)}

3-(1-Ferrocenylethyl)-pentane-2,4-dione: $0.50 \mathrm{~g}(1.60 \mathrm{mmol})$, toluene: $8.00 \mathrm{~mL}$, 1,2 ethylene diamine: $0.10 \mathrm{~mL}(1.60 \mathrm{mmol})$, eluent: hexane/ethyl acetate $(4: 1)$. Compound 2a was clearly observed as a yellow band (Rf: 0.9). Yield: $0.306 \mathrm{~g}$ (1.14 mmol, $71 \%$ ) of a yellow solid. Recrystallization of $\mathbf{2 a}$ from $\mathrm{CH}_{2} \mathrm{Cl}_{2}$ at rt produces suitable single crystals for X-ray diffraction study. M.p: $48-49{ }^{\circ} \mathrm{C}$. Anal. Calcd for $\mathrm{C}_{15} \mathrm{H}_{18} \mathrm{FeO}\left(270.16 \mathrm{~g} \mathrm{~mol}^{-1}\right)$ : C, 66.69; H, 6.72. Found: C, 66.53; H, 6.79. IR (KBr, cm ${ }^{-}$ $\left.{ }^{1}\right):$ 3092(w) $v\left(\mathrm{C}-\mathrm{H}\right.$ Arom), 2960(w), 2924(w) $v\left(\mathrm{C}-\mathrm{H}\right.$, alif), 1714(vs) $v(\mathrm{C}=\mathrm{O}) .{ }^{1} \mathrm{H}$ NMR $\left(400 \mathrm{MHz}_{\mathrm{CDCl}}\right): 1.56\left(\mathrm{~d},{ }^{3} \mathrm{~J}_{\mathrm{HH}}=5.9 \mathrm{~Hz}, 3 \mathrm{H}, \mathrm{CH}-\mathrm{CH}_{3}\right), 2.02\left(\mathrm{~s}, 3 \mathrm{H}, \mathrm{COCH}_{3}\right), 2.50$ $\left(\mathrm{dd}, J_{\mathrm{HH}}=16\right.$ and $\left.72 \mathrm{~Hz}, 2 \mathrm{H}, \mathrm{CH}_{2}\right), 2.97\left(\mathrm{~m}, 1 \mathrm{H}, \mathrm{CH}-\mathrm{CH}_{3}\right), 3.96\left(\mathrm{br} \mathrm{s}, 2 \mathrm{H}, \mathrm{C}_{5} \mathrm{H}_{4}\right)$, 4.00 (br s, $\left.2 \mathrm{H}, \mathrm{C}_{5} \mathrm{H}_{4}\right), 4.02$ (s, $\left.5 \mathrm{H}, \mathrm{C}_{5} \mathrm{H}_{5}\right) .{ }^{13} \mathrm{C}\left\{{ }^{1} \mathrm{H}\right\}$ NMR $\left(100 \mathrm{MHz}, \mathrm{CDCl}_{3}\right): 20.7$ $\left(\mathrm{CH}-\mathrm{CH}_{3}\right), 29.0\left(\mathrm{CH}-\mathrm{CH}_{3}\right), 30.8\left(\mathrm{COCH}_{3}\right), 52.6\left(\mathrm{CH}_{2}\right), 65.8\left(\mathrm{C}_{\alpha} \mathrm{C}_{5} \mathrm{H}_{4}\right), 67.1\left(\mathrm{C}_{\beta} \mathrm{C}_{5} \mathrm{H}_{4}\right)$, $68.4\left(\mathrm{C}_{5} \mathrm{H}_{5}\right), 94.6\left(\mathrm{C}_{\mathrm{ipso}} \mathrm{C}_{5} \mathrm{H}_{4}\right), 208.0(\mathrm{C}=\mathrm{O})$.

\subsubsection{1-(4-Methoxyphenyl)-3-ferrocenylbutane-1-one (2b)}

1-(4-Methoxyphenyl)-2-(1-ferrocenylethyl)-butane-1,3-dione: $0.31 \quad \mathrm{~g} \quad(0.77$ mmol), toluene: $5.0 \mathrm{~mL}, 1,2$-ethylene diamine: $50 \mu \mathrm{L}$ (0.77 mmol), eluent: hexane/ethyl acetate (4:1). Compound $\mathbf{2 b}$ was clearly observed as a yellow band (Rf: 0.8). Yield: $0.140 \mathrm{~g}(0.390 \mathrm{mmol}, 50 \%)$ of a yellow oil. Anal. Calcd for $\mathrm{C}_{21} \mathrm{H}_{22} \mathrm{FeO}_{2}\left(362.25 \mathrm{~g} \mathrm{~mol}^{-}\right.$ $\left.{ }^{1}\right)$ : C, 69.62; H, 6.12. Found: C, 69.52; H, 6.09. IR ( $\left.\mathrm{KBr}, \mathrm{cm}^{-1}\right)$ : 3094(w) $v(\mathrm{C}-\mathrm{H}$ arom), 2962(w), 2921(w), 2850(w) v(C-H, aliph), 1675(vs) v(C=O). ${ }^{1} \mathrm{H}$ NMR (400 MHz, $\mathrm{CDCl}_{3}$ ): 1.13 (br s, $3 \mathrm{H}, \mathrm{CH}_{3}-\mathrm{CH}$ ), 2.98 (br s, $2 \mathrm{H}, \mathrm{CH}_{2}$ ), 3.09 (br s, $1 \mathrm{H}, \mathrm{CH}-\mathrm{CH}_{3}$ ), 3.87 
(s, $3 \mathrm{H}, \mathrm{CH}_{3}-\mathrm{O}$ ), 4.42 (br s, $9 \mathrm{H}, \mathrm{C}_{5} \mathrm{H}_{4}$ and $\mathrm{C}_{5} \mathrm{H}_{5}$ ), $6.93\left(\mathrm{~d},{ }^{3} J_{\mathrm{HH}}=7.1 \mathrm{~Hz}, 2 \mathrm{H}, \mathrm{C}_{6} \mathrm{H}_{4}\right.$ ), $7.92\left(\mathrm{~d},{ }^{3} \mathrm{~J}_{\mathrm{HH}}=7.1 \mathrm{~Hz}, 2 \mathrm{H}, \mathrm{C}_{6} \mathrm{H}_{4}\right) .{ }^{13} \mathrm{C}\left\{{ }^{1} \mathrm{H}\right\} \mathrm{NMR}\left(100 \mathrm{MHz}, \mathrm{CDCl}_{3}\right): 20.77\left(\mathrm{CH}-\mathrm{CH}_{3}\right)$, $29.40\left(\mathrm{CH}-\mathrm{CH}_{3}\right), 47.16\left(\mathrm{OCH}_{3}\right), 55.48\left(\mathrm{CH}_{2}\right), 65.90\left(\mathrm{C}_{\alpha} \mathrm{C}_{5} \mathrm{H}_{4}\right), 68.05\left(\mathrm{C}_{\beta} \mathrm{C}_{5} \mathrm{H}_{4}\right), 69.43$ $\left(\mathrm{C}_{5} \mathrm{H}_{5}\right), 90.63\left(\mathrm{C}_{\text {ipso }} \mathrm{C}_{5} \mathrm{H}_{4}\right), 113.70\left(\mathrm{C}_{\mathrm{ipso}} \mathrm{C}_{6} \mathrm{H}_{4}\right) 130.43\left(\mathrm{C}_{6} \mathrm{H}_{4}\right) 130.48\left(\mathrm{C}_{6} \mathrm{H}_{4}\right) 163.37$ $\left(\mathrm{C}_{\text {ipso }} \mathrm{C}_{6} \mathrm{H}_{4} \mathrm{OMe}\right), 197.96(\mathrm{C}=\mathrm{O})$.

\subsubsection{1,3-BisFerrocenyl-butane-2-one (2c)}

1-Ferrocenyl-2-(1-ferrocenylethyl)-butane-1,3-dione: $0.20 \quad \mathrm{~g} \quad(0.45 \mathrm{mmol})$, toluene: $5.0 \mathrm{~mL}, 1,2$-ethylene diamine: $30 \mu \mathrm{L}$ (0.45 mmol), eluent: hexane/ethyl acetate (3:2). Compound 2c was clearly observed as an orange band (Rf: 0.5). Yield: $0.06 \mathrm{~g}$ $(0.13 \mathrm{mmol}, 31 \%)$ of a red solid. Suitable single crystals for the X-ray studies were obtained by slow diffusion of $n$-hexane into a dichloromethane solution at rt. M.p: 148$149{ }^{\circ} \mathrm{C}$. Anal. Calcd for $\mathrm{C}_{24} \mathrm{H}_{24} \mathrm{Fe}_{2} \mathrm{O}$ (440.14 $\mathrm{g} \mathrm{mol}^{-1}$ ): C, 65.49; H, 5.50. Found: C, 65.66; H, 5.79. IR (KBr, cm $\left.{ }^{-1}\right): 3089(w) v(\mathrm{C}-\mathrm{H}$ arom), 2962(w), 2928(w) 2861(w) $v(\mathrm{C}-$ $\mathrm{H}$, aliph), 1663(vs) $v(\mathrm{C}=\mathrm{O}) .{ }^{1} \mathrm{H}$ NMR (400 MHz, $\mathrm{CDCl}_{3}$ ): 1.14 (br s, $3 \mathrm{H}, \mathrm{CH}-\mathrm{CH}_{3}$ ), 2.82 (br s, $2 \mathrm{H}, \mathrm{CH}_{2}$ ), 2.97 (br s, $1 \mathrm{H}, \mathrm{CH}-\mathrm{CH}_{3}$ ), 4.10 (s, $5 \mathrm{H}, \mathrm{C}_{5} \mathrm{H}_{5} \mathrm{FcCO}$ ), 4.31 (br s, 9 $\mathrm{H}, \mathrm{C}_{5} \mathrm{H}_{4}$ and $\mathrm{C}_{5} \mathrm{H}_{5}$ ), 4.41 (br s, $2 \mathrm{H}, \mathrm{C}_{5} \mathrm{H}_{4} / \mathrm{FcCO}$ ), 4.69 (br s, $2 \mathrm{H}, \mathrm{C}_{5} \mathrm{H}_{4} / \mathrm{FcCO}$ ). ${ }^{13} \mathrm{C}\left\{{ }^{1} \mathrm{H}\right\}$ NMR (100 MHz, CDCl $)$ : $19.82\left(\mathrm{CH}-\mathrm{CH}_{3}\right), 28.01\left(\mathrm{CH}-\mathrm{CH}_{3}\right), 48.03\left(\mathrm{CH}_{2}\right), 66.52\left(\mathrm{C}_{\alpha}\right.$ $\left.\mathrm{C}_{5} \mathrm{H}_{4}\right), 67.93\left(\mathrm{C}_{\beta} \mathrm{C}_{5} \mathrm{H}_{4}\right), 68.42\left(\mathrm{C}_{5} \mathrm{H}_{5}\right), 78.49\left(\mathrm{C}_{\mathrm{ipso}} \mathrm{C}_{5} \mathrm{H}_{4}\right), 68.78\left(\mathrm{C}_{\alpha} \mathrm{C}_{5} \mathrm{H}_{4}\right), 69.62\left(\mathrm{C}_{\beta}\right.$ $\left.\mathrm{C}_{5} \mathrm{H}_{4}\right), 71.16\left(\mathrm{C}_{5} \mathrm{H}_{5}\right), 96.61\left(\mathrm{C}_{\text {ipso }} \mathrm{C}_{5} \mathrm{H}_{4}\right) 202.18(\mathrm{C}=\mathrm{O})$.

\subsection{Crystal structure determinations}

$\mathrm{X}$-ray data for compounds 2a and 2c were collected at 150(2) K on a Bruker APEXII AXS diffractometer, equipped with a CCD detector, using Mo-K $\alpha$ radiation ( $\lambda$ $=0.71073 \AA$ ). For each compound, a crystal of appropriate size was coated in Paratone$\mathrm{N}$ oil and mounted on a Kaptan loop. The loop was transferred to the diffractometer, centred in the beam, and cooled by a dinitrogen flow low-temperature apparatus that had been previously calibrated by a thermocouple placed at the same position as the crystal. The structures were solved by direct methods using SIR97 [41], and then refined with full-matrix least-square methods based on $F^{2}$ (SHELXL-97) [42], with the aid of WINGX [43], with all non-hydrogen atoms being refined anisotropically. The hydrogen atoms were included in calculated positions and were refined as riding atoms with isotropic displacement parameters. A summary of the details about crystal data 
collection parameters and refinement are documented in Table 1. Additional crystallographic details are in the CIF files. ORTEP views are generated using OLEX2 software [44].

Table 1 Crystallographic data and details of data collection and structure refinement parameters for compounds $\mathbf{2 a}$ and $\mathbf{2 c}$

\begin{tabular}{|c|c|c|}
\hline & $\mathbf{2 a}$ & 2c \\
\hline Empirical formula & $\mathrm{C}_{15} \mathrm{H}_{18} \mathrm{Fe} \mathrm{O}$ & $\mathrm{C}_{48} \mathrm{H}_{48} \mathrm{Fe}_{4} \mathrm{O}_{2}$ \\
\hline Formula mass $\left(\mathrm{g} \mathrm{mol}^{-1}\right)$ & 270.15 & 880.26 \\
\hline Collection $\mathrm{T}(\mathrm{K})$ & $150(2)$ & $150(2)$ \\
\hline Crystal system & Monoclinic & Triclinic \\
\hline Space group & $P 2{ }_{1} / a$ & P-1 \\
\hline $\mathrm{a}(\AA)$ & $8.7077(6)$ & $11.4691(10)$ \\
\hline $\mathrm{b}(\AA)$ & $9.8497(8)$ & $12.9925(9)$ \\
\hline$c(\AA)$ & $15.3006(12)$ & $14.1008(13)$ \\
\hline$\alpha\left({ }^{\circ}\right)$ & 90 & $66.749(3)$ \\
\hline$\beta\left(^{\circ}\right)$ & 104.733(3) & $81.895(3)$ \\
\hline$\gamma\left(\left(^{\circ}\right)\right.$ & 90 & $81.289(3)$ \\
\hline $\mathrm{V}\left(\AA^{3}\right)$ & $1269.16(17)$ & $1900.6(3)$ \\
\hline $\mathrm{Z}$ & 4 & 2 \\
\hline Dcalcd $\left(\mathrm{g} \mathrm{cm}^{-3}\right)$ & 1.414 & 1538 \\
\hline Crystal size $(\mathrm{mm})$ & $0.6 \times 0.5 \times 0.14$ & $0.31 \times 0.11 \times 0.03$ \\
\hline $\mathrm{F}(000)$ & 568 & 912 \\
\hline Absorption coefficient $\left(\mathrm{mm}^{-1}\right)$ & 1.168 & 1537 \\
\hline$\theta$ range $\left(^{\circ}\right)$ & 3.18 to 27.45 & 1.58 to 27.47 \\
\hline Range h,k, 1 & $-10 / 11,-12 / 12,-19 / 19$ & $-14 / 14,-16 / 16,-18 / 18$ \\
\hline No. independent refl. & 20473 & 18975 \\
\hline No. unique refl. (>2) & 2861 & 8492 \\
\hline Comp. to $\theta_{\max }(\%)$ & 99.0 & 99.5 \\
\hline Max/min transmission & $0.849 / 0.662$ & $0.955 / 0.764$ \\
\hline Data/restraints/parameters & $2861 / 0 / 156$ & $8492 / 0 / 489$ \\
\hline Final $R$ indices $[I>2 \sigma(I)]$ & $R 1^{a}=0.0878, w R 2^{b}=0.2577$ & $\mathrm{R} 1 \mathrm{a}=0.0522, \mathrm{wR} 2 \mathrm{~b}=0.1344$ \\
\hline $\mathrm{R}$ indices (all data) & $R 1^{a}=0.0933, w R 2^{b}=0.2607$ & $\mathrm{R} 1^{a}=0.1254, w R 2^{b}=0.183$ \\
\hline Goodness of fit/ $\mathrm{F}^{2}$ & 1.108 & 0.994 \\
\hline Largest diff. peak/hole $\left(\mathrm{e} \mathrm{A}^{-3}\right)$ & $3.709 /-2.007$ & $0.616 /-0.73$ \\
\hline
\end{tabular}

\section{Results and Discussion}

\subsection{Syntheses and characterization}

The syntheses of the organometallic ketones 2a-c were carried out in refluxing toluene, upon reacting the chiral $\beta$-diketones 1a-c with an equimolar amount of ethylenediamine for $12 \mathrm{~h}$, using glacial acetic acid as catalyst (see scheme 1). Compound 2a was isolated as a yellow powder, while compounds $\mathbf{2 b}$ and $\mathbf{2 c}$ were obtained as a yellow oil and a red powder, respectively, in yields ranging between 71 and $31 \%$, depending on the $\mathrm{R}$ substituent. This suggests that the steric more than 
electronic effect plays a significant role in the formation of the products, for which the yield decreases when the steric hindrance of the substituents of the starting diketone reagents increases. The electron donating abilities of both 4-methoxyphenyl and ferrocenyl groups are known to be similar [45]. The three organometallic ketones are air and moisture insensitive, thermally stables, and they are very soluble in solvents like dichloromethane, thf, ethyl acetate, but slightly soluble in hexane and diethyl ether.

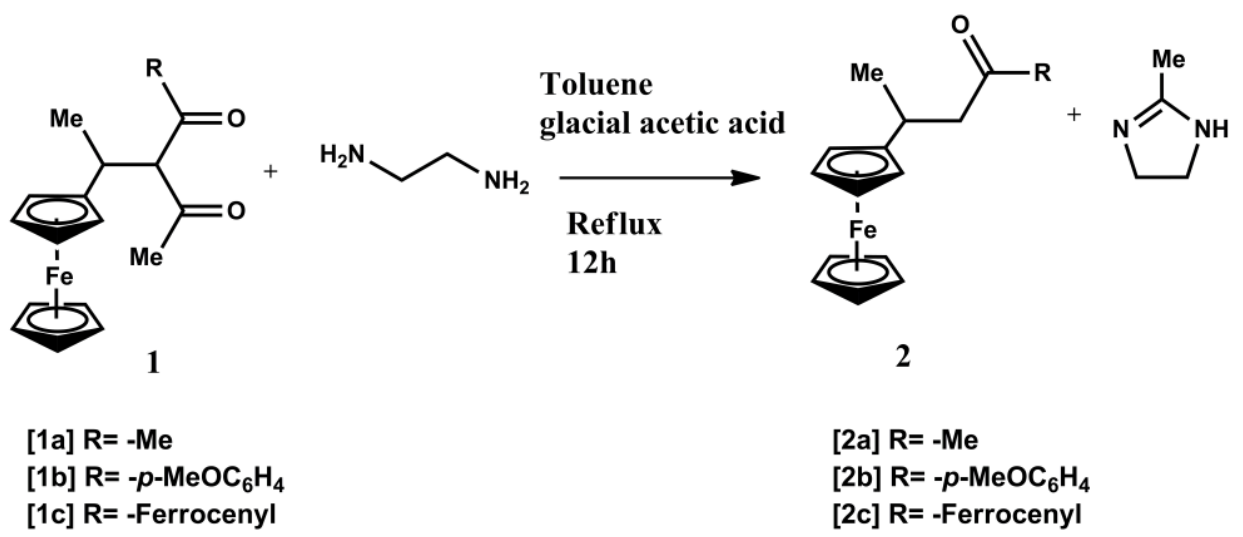

Scheme 1 Synthesis of compounds 2a-c

Reactions were also performed in $\mathrm{CH}_{2} \mathrm{Cl}_{2}$ as solvent, giving similar yield of $\mathbf{2 a}$ (70\%), while $\mathbf{2 b}$ and $\mathbf{2 c}$ could not be isolated in yields higher than $10 \%$. In addition to ketone $2 \mathbf{a}(\mathrm{m} / \mathrm{z}=270)$, the formation of 2-methyl-2-imidazoline $(\mathrm{m} / \mathrm{z}=84)$ [46] was also observed by GC-MS as the second reaction product. Under refluxing toluene conditions, the imidazoline derivative was not detected owing to its lack of thermal stability.

The compositions and identities of 2a-c were deduced from satisfactory elemental analysis, FT-IR, multinuclear and multi-dimensional NMR spectroscopy (see Section 2.2 for details). Additionally, the crystal and molecular structures of compounds 2a and 2c were solved by X-ray diffraction analysis.

The solid-state FT-IR spectra of compounds 2a-c exhibit similar features indicating analogous molecular structures. One of the weak $\mathrm{C}-\mathrm{H}$ stretching absorption bands in the $3100-3090 \mathrm{~cm}^{-1}$ range can be observed for the three compounds. On the other hand, the intense absorption bands observed in the $1714-1663 \mathrm{~cm}^{-1}$ range are due to the $(\mathrm{C}=\mathrm{O})$ stretching mode of the carbonyl group.

The ${ }^{1} \mathrm{H}$ NMR spectra of complexes $2 \mathbf{a}-\mathbf{c}$ recorded at $298 \mathrm{~K}$ in $\mathrm{CDCl}_{3}$, are consistent with the proposed structures. In each ${ }^{1} \mathrm{H}$ NMR spectrum, the 
[FcCH$\left.\left(\mathrm{CH}_{3}\right) \mathrm{CH}_{2}-\right]$ fragment is clearly identified by the following characteristic multiplicity scheme; the ferrocenyl fragment consists in a group of three signals in the range 3.96-4.41 ppm which are assigned to the free $\mathrm{C}_{5} \mathrm{H}_{5}$ ring, and to the two types of protons $\left(\mathrm{H}_{\alpha}\right.$ and $\left.\mathrm{H}_{\beta}\right)$ of the substituted cyclopentadienyl ring with the integration ratio $5: 2: 2$. This contrasts with the spectra of their respective precursors 1a-c where the two pairs of diastereotopic $\mathrm{H}_{\alpha}, \mathrm{H}_{\alpha}$, and $\mathrm{H}_{\beta}, \mathrm{H}_{\beta}$, protons give rise to four resonances integrating

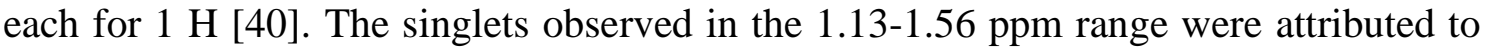
the methyl protons while the resonances appearing in the 2.97-3.08 ppm and 2.50-2.98 ppm ranges were attributed to the proton resonances of the $-\mathrm{CH}-$ and $-\mathrm{CH}_{2}$ - units, respectively. Again, the two diastereotopic protons of the $\mathrm{CH}_{2}$ unit are not distinguished. In addition, the sharp peaks at $2.02 \mathrm{ppm}$ for $\mathbf{2 a}, 3.87 \mathrm{ppm}$ for $\mathbf{2} \mathbf{b}$ and 4.10 ppm for 2c, are unambiguously assigned to the methyl, the methoxy and the free cyclopentadienyl protons of the carbonyl substituent, respectively.

The ${ }^{13} \mathrm{C}$ NMR spectra of complexes 2a-c confirm the behavior observed in ${ }^{1} \mathrm{H}$ NMR spectra. For the $\left[\mathrm{Fc}-\mathrm{CH}\left(\mathrm{CH}_{3}\right)-\mathrm{CH}_{2}-\right]$ fragment, the ferrocenyl moiety resonates as four signals with classical chemical shifts, instead of the six resonances expected for the two pairs of diastereotopic $\mathrm{C}_{\alpha}$ and $\mathrm{C}_{\beta}$ carbons [40]. The signals observed in the 19.8220.77 ppm, 28.01-29.40 ppm and 48.02-55.48 ppm ranges were attributed to the $\mathrm{CH}_{3}$, $\mathrm{CH}$ and $\mathrm{CH}_{2}$ carbon atoms, respectively. On the other hand, the carbonyl carbons showed up in the expected low-field region at 208.0, 197.96 and $202.18 \mathrm{ppm}$ for $\mathbf{2 a}, \mathbf{2 b}$ and $\mathbf{2 c}$, respectively.

\subsection{X-ray crystallographic studies}

Perspective views of compounds $2 \mathbf{a}$ and $\mathbf{2 c}$ with the atom labeling scheme are shown in Figs. 1 and 2, while selected bond distances and angles are listed in Tables 2 and 3, respectively. Ketone 2a crystallizes in the monoclinic centrosymmetric space group $\mathrm{P} 2{ }_{1} / \mathrm{a}$ with a single molecule in the asymmetric unit, whereas the ketone $\mathbf{2 c}$ crystallizes in the triclinic centrosymmetric space group P-1, with two molecules in the asymmetric unit, one molecule with two eclipsed ferrocenyl moieties (Fe1a and Fe2a) and, the other molecule, with one ferrocenyl moiety eclipsed (Fe1) and the other alternated (Fe2). The molecular structure shows that each compound is formed by the $\left[\mathrm{Fc}-\mathrm{CH}\left(\mathrm{CH}_{3}\right)-\mathrm{CH}_{2}-\right.$ $\mathrm{C}(\mathrm{O})$-] fragment, substituted by a methyl group in $\mathbf{2 a}$ and by a ferrocenyl moiety in $\mathbf{2 c}$. Crystal cell of $\mathbf{2 a}$ and $\mathbf{2 c}$ contain both enantiomers with the (R) and (S) configuration 
for the chiral $\mathrm{C}(11)$ atom. Both enantiomeric forms are related by a symmetry plane with inversion of the configuration at each carbon atom.

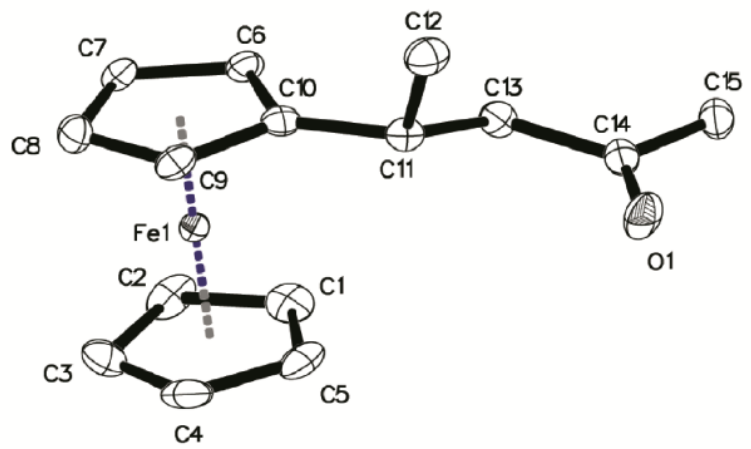

Fig. 1 Molecular structure of $\mathbf{2 a}$ with the atom numbering schemes. Hydrogen atoms have been omitted for clarity. Thermal ellipsoids are drawn at 50\% probability.

Table 2 Selected bond distances $(\AA)$ and angles $\left({ }^{\circ}\right)$, and torsion angles $\left(^{\circ}\right)$ for $\mathbf{2 a}$

\begin{tabular}{llll}
\hline \multicolumn{5}{c}{ Bond distances } \\
\hline $\mathrm{C}(10)-\mathrm{C}(11)$ & $1.515(9)$ & $\mathrm{C}(11)-\mathrm{C}(12)$ & $1.525(9)$ \\
$\mathrm{C}(11)-\mathrm{C}(13)$ & $1.523(9)$ & $\mathrm{C}(13)-\mathrm{C}(14)$ & $1.512(9)$ \\
$\mathrm{C}(14)-\mathrm{C}(15)$ & $1.503(9)$ & $\mathrm{C}(14)-\mathrm{O}(1)$ & $1.210(9)$ \\
$\mathrm{Fe}(1)-\mathrm{C}(1-5)$ avg & 2.044 & $\mathrm{Fe}(1)-\mathrm{C}(6-10)$ avg & 2.046 \\
\hline \multicolumn{5}{c}{ Bond Angles } \\
\hline $\mathrm{C}(10)-\mathrm{C}(11)-\mathrm{C}(12)$ & $110.9(6)$ & $\mathrm{C}(10)-\mathrm{C}(11)-\mathrm{C}(13)$ & $111.6(5)$ \\
$\mathrm{C}(11)-\mathrm{C}(13)-\mathrm{C}(14)$ & $115.5(5)$ & $\mathrm{C}(13)-\mathrm{C}(14)-\mathrm{C}(15)$ & $114.5(6)$ \\
$\mathrm{O}(1)-\mathrm{C}(14)-\mathrm{C}(13)$ & $123.3(6)$ & $\mathrm{O}(1)-\mathrm{C}(14)-\mathrm{C}(15)$ & $122.1(6)$ \\
\hline \multicolumn{5}{c}{ Torsion Angles } \\
\hline $\mathrm{C}(10)-\mathrm{C}(11)-\mathrm{C}(13)-\mathrm{C}(14)$ & $-165.8(6)$ & $\mathrm{C}(11)-\mathrm{C}(13)-\mathrm{C}(14)-$ & $-166.4(6)$ \\
& \multicolumn{5}{c}{} \\
\hline
\end{tabular}

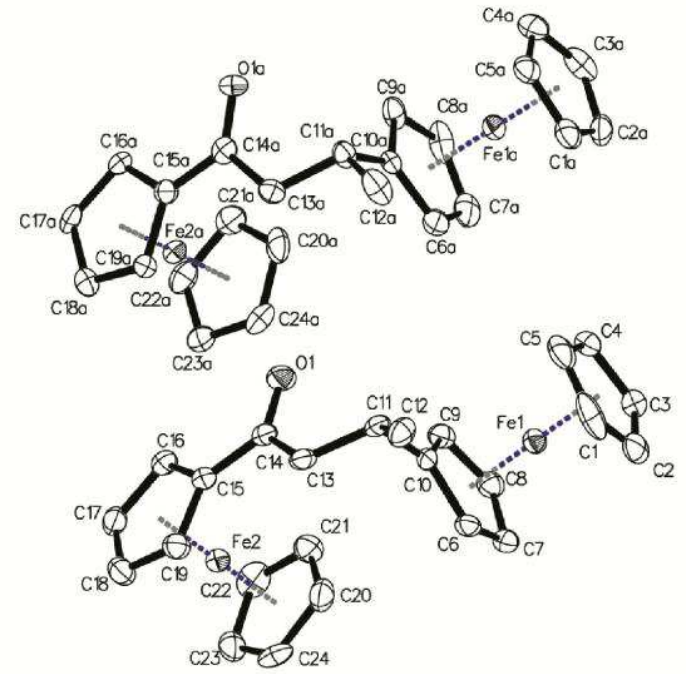

Fig. 2 Molecular structure of $\mathbf{2 c}$ with the atom numbering schemes, showing the two independent molecules, that with the two eclipsed ferrocenes (top) and that with an 
eclipsed and a staggered ferrocene (bottom). Hydrogen atoms have been omitted for clarity. Thermal ellipsoids are drawn at $50 \%$ probability.

Table 3 Selected bond distances $(\AA)$ and angles $\left({ }^{\circ}\right)$, and torsion angles $\left(^{\circ}\right)$ for $\mathbf{2 c}$

\begin{tabular}{|c|c|c|c|}
\hline \multicolumn{4}{|c|}{ Bond distances } \\
\hline $\mathrm{C}(10)-\mathrm{C}(11)$ & $1.494(7)$ & $C(10 a)-C(11 a)$ & $1.498(7)$ \\
\hline $\mathrm{C}(11)-\mathrm{C}(12)$ & $1.522(7)$ & $C(11 a)-C(12 a)$ & $1.540(7)$ \\
\hline $\mathrm{C}(11)-\mathrm{C}(13)$ & $1.533(7)$ & $C(11 a)-C(13 a)$ & $1.541(7)$ \\
\hline $\mathrm{C}(13)-\mathrm{C}(14)$ & $1.504(7)$ & $C(13 a)-C(14 a)$ & $1.529(7)$ \\
\hline$C(14)-C(15)$ & $1.471(7)$ & $C(14 a)-C(15 a)$ & $1.468(7)$ \\
\hline $\mathrm{C}(14)-\mathrm{O}(1)$ & $1.227(6)$ & $\mathrm{C}(14 \mathrm{a})-\mathrm{O}(1 \mathrm{a})$ & $1.223(6)$ \\
\hline $\mathrm{Fe}(1)-\mathrm{C}(1-5)^{\mathrm{a}}$ & 2.038 & $\operatorname{Fe}(1 a)-C(1 a-5 a)^{a}$ & 2.038 \\
\hline $\mathrm{Fe}(1)-\mathrm{C}(6-10)^{\mathrm{a}}$ & 2.048 & $\mathrm{Fe}(1 \mathrm{a})-\mathrm{C}(6 \mathrm{a}-10 \mathrm{a})^{\mathrm{a}}$ & 2.043 \\
\hline $\mathrm{Fe}(2)-\mathrm{C}(15-19)^{\mathrm{a}}$ & 2.057 & $\operatorname{Fe}(2 a)-C(15 a-19 a)^{a}$ & 2.050 \\
\hline $\mathrm{Fe}(2)-\mathrm{C}(20-24)^{\mathrm{a}}$ & 2.045 & $\mathrm{Fe}(2 \mathrm{a})-\mathrm{C}(20 \mathrm{a}-24 \mathrm{a})^{\mathrm{a}}$ & 2.047 \\
\hline \multicolumn{4}{|c|}{ Bond Angles } \\
\hline $\mathrm{C}(10)-\mathrm{C}(11)-\mathrm{C}(12)$ & $114.1(4)$ & $\begin{array}{l}C(10 a)-C(11 a)- \\
C(12 a)\end{array}$ & $113.4(5)$ \\
\hline $\mathrm{C}(10)-\mathrm{C}(11)-\mathrm{C}(13)$ & $109.6(4)$ & $\begin{array}{l}C(10 a)-C(11 a)- \\
C(13 a)\end{array}$ & $109.6(4)$ \\
\hline $\mathrm{C}(11)-\mathrm{C}(13)-\mathrm{C}(14)$ & $114.3(5)$ & $\begin{array}{l}C(11 a)-C(13 a)- \\
C(14 a)\end{array}$ & $114.6(4)$ \\
\hline $\mathrm{O}(1)-\mathrm{C}(14)-\mathrm{C}(13)$ & $121.2(5)$ & $\mathrm{O}(1)-\mathrm{C}(14 \mathrm{a})-\mathrm{C}(13 \mathrm{a})$ & $121.0(5)$ \\
\hline $\mathrm{O}(1)-\mathrm{C}(14)-\mathrm{C}(15)$ & $120.4(5)$ & $\mathrm{O}(1 \mathrm{a})-\mathrm{C}(14 \mathrm{a})-\mathrm{C}(15 \mathrm{a})$ & $121.1(5)$ \\
\hline \multicolumn{4}{|c|}{ Torsion Angles } \\
\hline $\mathrm{C}(10)-\mathrm{C}(11)-\mathrm{C}(13)-\mathrm{C}(14)$ & $-72.4(6)$ & $\begin{array}{l}C(10 a)-C(11 a)- \\
C(13 a)-C(14 a)\end{array}$ & $-71.3(6)$ \\
\hline $\mathrm{C}(11)-\mathrm{C}(13)-\mathrm{C}(14)-\mathrm{C}(15)$ & $161.8(5)$ & $\begin{array}{l}C(11 a)-C(13 a)- \\
C(14 a)-C(15 a)\end{array}$ & $161.0(5)$ \\
\hline
\end{tabular}

${ }^{a}$ Average value

In each compound, the ferrocenyl group with co-planar cyclopentadienyl rings features a linear sandwich structure with a typical $\left[\eta^{5}-\mathrm{Fe}-\eta^{5}\right]$ coordination mode. The iron atom is coordinated to the free and substituted cyclopentadienyl rings at a ring centroid-iron distances of 1.645/1.645 $\AA$ for $\mathbf{2 a}, 1.645 / 1.645 \AA$ (Fe1a) and 1.654/1.652 (Fe2a), 1.649/1.649 $\AA(\mathrm{Fe} 1)$ and 1.660/1.655 $\AA$ (Fe2) for 2c, with ring centroid-ironring centroid angle of $179.3^{\circ}(\mathrm{Fe} 1)$ for $2 \mathbf{a}, 179.88^{\circ}(\mathrm{Fe} 1 \mathrm{a}), 178.94^{\circ}(\mathrm{Fe} 2 \mathrm{a})$ and $178.72^{\circ}$ $(\mathrm{Fe} 1), 179.38^{\circ}(\mathrm{Fe} 2)$ for $2 \mathrm{c}$, respectively, indicating that there is a $\mathrm{Fe}(\mathrm{II})$ oxidation state in each metallocene [47].

On the other hand, the measured distances of $\mathrm{C}(14)-\mathrm{O}(1)$ and $\mathrm{C}(14 \mathrm{a})-\mathrm{O}(1 \mathrm{a})$ bond lengths of compounds $2 \mathbf{a}(1.210(9) \AA)$ and $2 \mathbf{c}(1.227(6)$ and 1.223(6) $\AA$ ), respectively, are typical of a $\mathrm{C}=\mathrm{O}$ double bond [48]. As expected and reported previously [40], in the two crystallographically independent molecules of $\mathbf{2 c}$, the fragments $\mathrm{O}(1)-\mathrm{C}(14)-\mathrm{C}(15)$ 
and $\mathrm{O}(1 \mathrm{a})-\mathrm{C}(14 \mathrm{a})-\mathrm{C}(15 \mathrm{a})$ are almost co-planar with their respective attached cyclopentadienyl ring $\mathrm{C}(15){ }^{\cdots} \mathrm{C}(19)$ and $\mathrm{C}(15 \mathrm{a}){ }^{\cdots} \mathrm{C}(19 \mathrm{a})$ with dihedral angles of $5.16^{\circ}$ and $5.12^{\circ}$.

The crystal structures of $\mathbf{2 a}$ and $\mathbf{2 c}$, exhibit short intermolecular contacts. For instance, intermolecular $\mathrm{C}-\mathrm{H} \cdots \mathrm{O}$ hydrogen bonds (Table 4) generate a stair-type structure in compound 2a, and a chain structure in compound 2c (see Fig. 3).
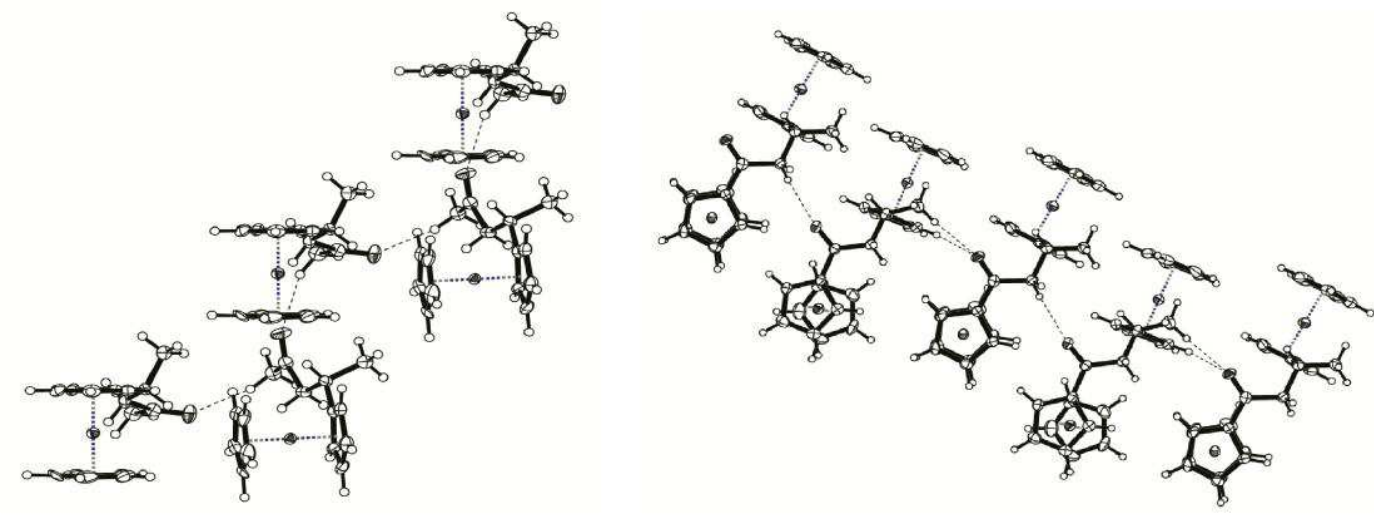

Fig. 3 Intermolecular hydrogen bond interactions forming a stair-type structure in 2a (left), and a chain structure in $\mathbf{2 c}$ (right)

Table 4 Hydrogen bond interactions parameters for compounds $\mathbf{2 a}$ and $\mathbf{2 c}$

\begin{tabular}{clcccc}
\hline Compd & \multicolumn{1}{c}{$\mathrm{D}-\mathrm{H} \cdots \mathrm{A}(\AA)$} & $\mathrm{D}-\mathrm{H}(\AA)$ & $\mathrm{H} \cdots \mathrm{A}(\AA)$ & $\mathrm{D} \cdots \mathrm{A}(\AA)$ & $\mathrm{D}-\mathrm{H} \cdots \mathrm{A}\left({ }^{\circ}\right)$ \\
\hline $\mathbf{2 a}$ & $\mathrm{C} 15-\mathrm{H} 16 \cdots \mathrm{O} 1^{\mathrm{i}}$ & 0.98 & 2.53 & $3.417(10)$ & 151 \\
\hline \multirow{2}{*}{$\mathbf{2 c}$} & $\mathrm{C} 12-\mathrm{H} 15 \mathrm{a} \cdots \mathrm{O} 1 \mathrm{a}^{\mathrm{ii}}$ & 0.98 & 2.47 & $3.435(7)$ & 170 \\
& $\mathrm{C} 6-\mathrm{H} 20 \cdots \mathrm{O} 1 \mathrm{a}^{\mathrm{ii}}$ & 0.95 & 2.39 & $3.311(6)$ & 165 \\
& $\mathrm{C} 13 \mathrm{~A}-\mathrm{H} 63 \mathrm{~A} \cdots \mathrm{O} 1$ & 0.99 & 2.50 & $3.447(6)$ & 160 \\
\hline
\end{tabular}

Symmetry codes: (i) $1 / 2+\mathrm{x},-1 / 2-\mathrm{y}, \mathrm{z}$; (ii) $1+\mathrm{x}, \mathrm{y}, \mathrm{z}$

\subsection{Mechanistic aspects}

The mechanism showed in Scheme 2 is similar to that described by Angelov [46], where the same specific fragmentation of an enamine was observed. In the present case, we consider two routes for the formation of the enamine: (i) the direct formation of the enamine $[\mathbf{I}]$, owing to the proton acidity of the tertiary central carbon of the $\beta$ diketone 1 (a route that has been suggested in aqueous medium catalysis [49]), and (ii) the imine [II] formation and its subsequent conversion to enamine [I]. This imineenamine tautomerism is favored by stabilization through conjugation of the carbonyl 
group and the carbon-carbon double bond [50-53]. In both cases, the nucleophilic attack of the amine group would be the rate-limiting step of the reaction. Subsequently, an intramolecular Michael addition reaction of the free amine onto the enamine carbon atom would form the five-membered heterocycle of intermediate [III], followed by retro-Mannich fragmentation to generate the enol derivative [IV] and the 2methylimidazole. Enols [IV] must isomerize rapidly to their respective keto tautomers 2 as none of them could be identified by ${ }^{1} \mathrm{H}$ NMR or FT-IR spectroscopy [33]. Although the intermediates $[\mathbf{I}],[\mathbf{I I}]$ and $[\mathbf{I I I}]$ were not isolated nor spectroscopically characterized, the proposed mechanism relies on the nature of the substituted organometallic ketones that were obtained in good yields, and the formation of 2methyl-4,5-dihydro-1-H-imidazole has been verified.

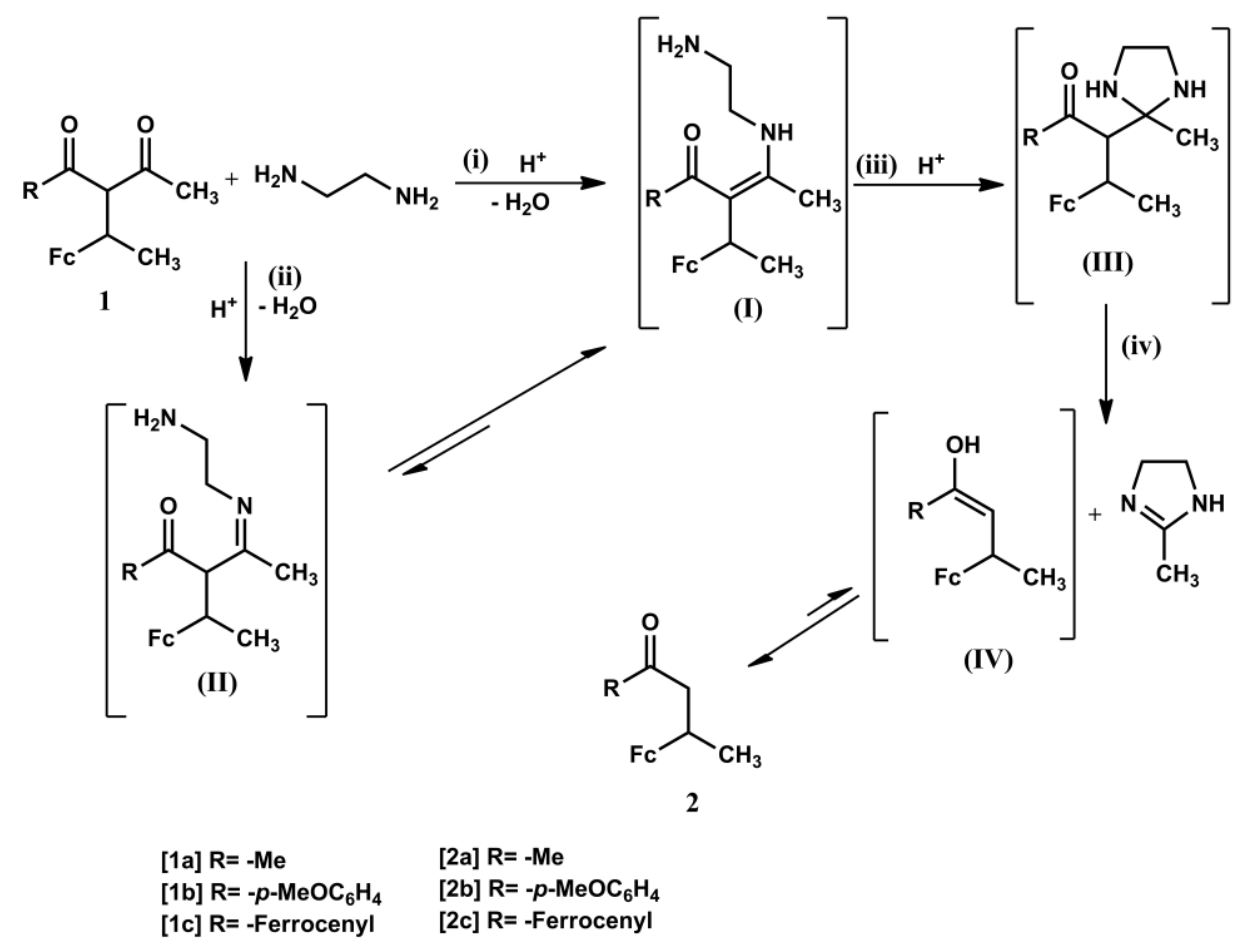

Scheme 2 Proposed mechanism for the formation of ketones $\mathbf{2 a - c}$ 


\subsection{Cyclic voltammetry measurements}

The electrochemical behavior of the bimetallic compound $2 \mathbf{c}$ was investigated by cyclic voltammetry in dichloromethane solution containing $0.1 \mathrm{Mn} n-\mathrm{Bu}_{4} \mathrm{~N}^{+} \mathrm{PF}_{6}^{-}$as supporting electrolyte. The measurements were carried out using $1.0 \mathrm{mM}$ solution of $\mathbf{2 c}$ at room temperature in the potential range of +1.5 to $-1.0 \mathrm{~V}$, with scan rate of $100 \mathrm{mV} \mathrm{s}^{-}$

1. Cyclic voltammogram (CV) of the solution containing $2 \mathbf{c}$ shows one chemically reversible oxidation process with current ratio $\mathrm{i}_{\mathrm{pa}} / \mathrm{i}_{\mathrm{pc}}$ equal to unity, at $E_{1 / 2}$ value identical, within the experimental errors, to that of the $\mathrm{FcH}^{0} / \mathrm{FcH}^{+}$couple $\left(E_{1 / 2}=0.510\right.$ V) taken as internal reference. The anodic to cathodic peak-to-peak separations is similar to that observed for free ferrocene under identical conditions, indicating that it is likely a one-electron oxidation of the 1-ferrocenylethyl entity to its ferricenium counterpart $2 \mathbf{c}^{+}$at the electrode. In addition, the CV of $\mathbf{2 c}$ exhibited also a second reversible wave at $E_{1 / 2}=0.760 \mathrm{~V}$, attributable to the mono-electronic oxidation of the ferrocenoyl moiety. Such a strong positive shift $(0.250 \mathrm{~V})$ with respect to free ferrocene, is presumably due to the electron withdrawing effect of the cationic $\left[\mathrm{Fc}-\mathrm{CH}\left(\mathrm{CH}_{3}\right)-\mathrm{CH}_{2}-\right.$ $\mathrm{C}(=\mathrm{O})]^{+}$substituent. This value is identical to that found for acetylferrocene [54], suggesting that there is no electronic interaction between the two ferrocenyl moieties separated by four single bonds

\section{Conclusions}

In the present work we describe the reactivity of chiral ferrocenyl-containing $\beta$ diketones toward ethylene diamine and the full analytical and spectroscopic characterization of the resulting monoketonic products. In addition, the mononuclear complex $\mathbf{2 a}$ and the bimetallic derivative $\mathbf{2 c}$ were authenticated by means of X-ray diffraction analysis. The three starting chiral $\beta$-diketones follow a similar fragmentation pathway according to a domino sequence of intramolecular Michael addition and retroMannich rearrangement, giving rise to their respective deacetylated counterparts and formation of 2-methyl-2-imidazoline, a class of compounds that have attracted considerable attention in recent years in the development of compounds with pharmacological properties [55]. 


\section{Acknowledgements}

The authors thank Dr. S. Sinbandhit (CRMPO, Rennes) for helpful assistance with NMR experiments. This research has been performed as part of the Chilean-French International Associated Laboratory for "Inorganic Functional Materials" (LIAMIFCNRS N ${ }^{\circ} 36$ ). Financial support from the Fondo Nacional de Desarrollo Científico y Tecnológico [FONDECYT (Chile), grant no. 1090310 (C.M. and D.C.)], the Vicerrectoría de Investigación y Estudios Avanzados, Pontificia Universidad Católica de Valparaíso, Chile (C.M. and D.C.), the CNRS and the Université de Rennes 1 is gratefully acknowledged. G.A. Thanks the CONICYT (Chile) for support of a graduate student fellowship.

\section{Appendix A. Supplementary material}

CCDC 1007151 (for 2a) and 1007152 (for 2c) contain the supplementary crystallographic data for this paper. These data can be obtained free of charge from the Cambridge Crystallographic Data Centre via www.ccdc.cam.as.uk/data_request/cif.

\section{References}

[1] P.A. Vigato, V. Peruzzo, S. Tamburini, Coord. Chem. Rev. 256 (2012) 953.

[2] C.J. Whiteoak, G. Salassa, A.W. Kleij, Chem. Soc. Rev. 41 (2012) 622.

[3] N. Novoa, J.P. Soto, R. Henríquez, C. Manzur, D. Carrillo, J.-R. Hamon, J. Inorg. Organomet. Polym. Mater. 23 (2013) 1247.

[4] M. Fuentealba, J.-R. Hamon, D. Carrillo, C. Manzur, New J. Chem. 31 (2007) 1815.

[5] A. Decortes, A.M. Castilla, A.W. Kleij, Angew. Chem. Int. Ed. 49 (2010) 9822.

[6] D.J. Darensbourg, Chem. Rev. 107 (2007) 2388.

[7] K. Matsumoto, B. Saito, T. Katsuki, Chem. Commun. (2007) 3619.

[8] C. Baleizo, H. Garcia, Chem. Rev. 106 (2006) 3987.

[9] E.M. McGiarrigle, D.G. Gilheany, Chem. Rev. 105 (2005) 1563. 
[10] P.G. Cozzi, Chem. Soc. Rev. 33 (2004) 410.

[11] E.N. Jacobsen, Acc. Chem. Res. 33 (2000) 421.

[12] L. Canali, D.C. Sherrington, Chem. Soc. Rev. 28 (1999) 85.

[13] T. Rosu, E. Pahontu, M. Reka-Stefana, C. Ilies, R. Georgescu, S. Shova, A. Gulea, Polyhedron 31 (2012) 352.

[14] M. Rajasekar, S. Sreedaran, R. Prabu, V. Narayanan, R. Jegadeesh, N. Raaman, A.K. Rahiman, J. Coord. Chem. 63 (2010) 136.

[15] S.M. Abdallah, G.G. Mohamed, M.A. Zayed, M.S.A. El-Ela, Spectrochim. Acta A 73 (2009) 833.

[16] C. Wang, X. Wu, S. Tu, B. Jiang, Synth. React. Inorg. Met. Org. Nano-Met. Chem. 39 (2009) 78.

[17] M.S. Karthikeyan, D.J. Parsad, B. Poojary, K.S. Bhat, B.S. Holla, N.S. Kumari, Bioorg. Med. Chem. 14 (2006) 7482.

[18] C. Gallardo, A. Trujillo, M. Fuentealba, A. Vega, D. Carrillo, C. Manzur, J. Chil. Chem. Soc. 52 (2007) 1266.

[19] C.-M. Che, C.-C. Kwok, S.-W. Lai, A.F. Rausch, W.J. Finkenzeller, N. Zhu, H. Yersin, Chem. Eur. J. 16 (2010) 233.

[20] T. Akitsu, T. Itoh, Polyhedron 29 (2010) 477.

[21] S. Yang, H. Kou, H. Wang, K. Cheng, J. Wang, New J. Chem. 34 (2010) 313.

[22] T.M. Ross, S.M. Neville, D.S. Innes, D.R. Turner, B. Moubaraki, K.S. Murray, Dalton Trans. 39 (2010) 149.

[23] B. Weber, Coord. Chem. Rev. 253 (2009) 2432.

[24] S.J. Wezenberg, A.W. Kleij, Angew. Chem. Int. Ed. 47 (2008) 2354. 
[25] S. Di Bella, I. Pietro Oliveri, A. Colombo, C. Dragonetti, S. Righetto, D. Roberto, Dalton Trans. 41 (2012) 7013.

[26] A. Trujillo, M. Fuentealba, D. Carrillo, C. Manzur, I. Ledoux-Rak, J.-R. Hamon, J.-Y. Saillard, Inorg. Chem. 49 (2010) 2750.

[27] J. Gradinaru, A. Forni, V. Druta, F. Tessore, S. Zecchin, S. Quici, N. Garbalau, Inorg. Chem. 46 (2007) 884.

[28] L. Rigamonti, F. Demartin, A. Forni, S. Righetto, A. Pasini, Inorg. Chem. 45 (2006) 10976.

[29] J.-P. Costes, J.F. Lamère, C. Lepetit, P.G. Lacroix, F. Dahan, K. Nakatani, Inorg. Chem. $44(2005) 1973$.

[30] M.L.H. Green, S.R. Marder, M.E. Thompson, J.A. Bandy, D. Bloor, P.V. Kolinsky, R.J. Jones, Nature 330 (1987) 26.

[31] A.L. Gavrilova, B. Bosnich, Chem. Rev. 104 (2004) 349.

[32] P.J. Steel, Acc. Chem. Res. 38 (2005) 243.

[33] S. Celedon, M. Fuentealba, T. Roisnel, J.-R. Hamon, D. Carrillo, C. Manzur, Inorg. Chim. Acta 390 (2012) 184.

[34] M. Fuentealba, A. Trujillo, J.-R. Hamon, D. Carrillo, C. Manzur, J. Mol. Struct. 881 (2008) 76.

[35] J.-P. Costes, G. Cros, C. R. Acad. Sci. Ser. 294 (1982) 173.

[36] G. Bett, D.E. Fenton, J.R. Tate, Inorg. Chim. Acta. 54 (1981) L101.

[37] J.-P. Costes, D.E. Fenton, J. Chem. Soc., Dalton Trans. (1983) 2235.

[38] M.M. Tamizh, B.F.T. Cooper, C.L.B. Macdonald, R. Karvembu, Inorg. Chim. Acta 394 (2013) 391. 
[39] M.M. Tamizh, K. Mereiter, K. Kirchner, R. Karvembu, J. Organomet. Chem. 700 (2012) 194.

[40] G. Ahumada, T. Roisnel, S. Sinbandhit, C. Manzur, D. Carrillo, J.-R. Hamon, J. Organomet. Chem. 737 (2013) 1.

[41] A. Altomare, M.C. Burla, M. Camalli, G. Cascarano, C. Giacovazzo, A. Guagliardi, A.G.G. Moliterni, G. Polidori, R. Spagna, J. Appl. Crystallogr. 32 (1999) 115.

[42] G.M. Sheldrick, Acta Crystallogr. A64 (2008) 112.

[43] L.J. Farrugia, J. Appl. Crystallogr. 32 (1999) 837.

[44] O. V. Dolomanov, L.J. Bourhis, R.J. Gildea, J.A.K. Howard, H. Puschmann, J. Appl. Crystallogr. 42 (2009) 339.

[45] A.N. Nesmeyanov, E.G. Perevalova, S.P. Gubin, K.I. Granberg, A.G. Kozlovsky, Tetrahedron Lett. 7 (1966) 2381.

[46] P. Angelov, Synlett (2010) 1273.

[47] J.D. Dunitz, L.E. Orgel, A. Rich, Acta Crystallogr. 9 (1956) 373.

[48] F.H. Allen, O. Kennard, D.G. Watson, L. Brammer, A.G. Orpen, R. Taylor, J. Chem. Soc. Perkin Trans. S1 (1987).

[49] X. Zhu, F. Tanaka, R.A. Lerner, C.F. Barbas, I.A. Wilson, J. Am. Chem. Soc. 131 (2009) 18206.

[50] R.A. Clark, D.C. Parker, J. Am. Chem. Soc. 93 (1971) 7257.

[51] G.O. Dudek, R.H. Holm, J. Am. Chem. Soc. 83 (1961) 2099.

[52] G.O. Dudek, R.H. Holm,J. Am. Chem; Soc; 83 (1961) 3914.

[53] S. Forsen, M. Nillson, Ark. Kemi. 19 (1962) 569.

[54] N.G. Connelly, W.E. Geiger, Chem. Rev. 96 (1996) 877. 
[55] S.R.S. Saibabu Kotti, C. Timmons, G. Li, Chem. Biol. Drug. Des. 67 (2006) 101. 